\title{
Genetic Analysis of Resistance to Leaf Rust and Stripe Rust in Wheat Cultivar Francolin\#1
}

C. X. Lan and R. P. Singh, International Maize and Wheat Improvement Center (CIMMYT), 06600, México D.F., Mexico; J. HuertaEspino, Campo Experimental Valle de México INIFAP, 56230, Chapingo, Edo. de México, Mexico; and V. Calvo-Salazar and S. A. Herrera-Foessel, International Maize and Wheat Improvement Center (CIMMYT), 06600, México D.F., Mexico

\begin{abstract}
Lan, C. X., Singh, R. P., Huerta-Espino, J., Calvo-Salazar, V., and Herrera-Foessel, S. A. 2014. Genetic analysis of resistance to leaf rust and stripe rust in wheat cultivar Francolin\#1. Plant Dis. 98:1227-1234.

Leaf rust and stripe rust are important diseases of wheat and can be controlled by growing resistant varieties. We investigated the genetic basis of resistance to both rusts in $198 \mathrm{~F}_{5}$ recombinant inbred lines derived from a cross between 'Avocet' and 'Francolin\#1'. The population was phenotyped in greenhouse and field, and genotyped with known gene-associated molecular markers. Seedling resistance of Francolin\#1 to leaf and stripe rusts was attributed to the loosely linked genes $\operatorname{Lrl6}$ and $\mathrm{YrF}$, respectively, with a recombination frequency of 0.36 . Field segregation indicated that adult plant resistance (APR) to leaf and stripe rusts was conferred by three and five additive genes,

respectively. Among them, $L r 46 / Y r 29$ was associated with resistance to both rusts in Francolin\#1, Lrl6 reduced field leaf rust severity by 8 to $9 \%$, and $\mathrm{YrF}$ contributed to 10 to $25 \%$ reductions in stripe rust severity. The $L r 16$ region was also associated with a 5 to $16 \%$ reduction in stripe rust severity, which is likely due to its linkage with $\operatorname{YrF}$ or another unidentified stripe rust APR gene. Significant additive effects on stripe rust were detected between $Y r F$ and $Y r 29$. We conclude that APR in Francolin\#1 to leaf and stripe rusts involves a combination of seedling and APR genes.
\end{abstract}

Leaf (or brown) rust and stripe (or yellow) rust, caused by Puccinia triticina and $P$. striiformis $\mathrm{f}$. sp. tritici, respectively, are important diseases of wheat worldwide. Stripe rust is currently receiving increased interest due to the detection of more virulent and aggressive races, which are more destructive to common wheat (Triticum aestivum L.) than older races $(2,26)$. In addition, both rusts have been reported in areas where these diseases were previously rarely detected (2). Yield losses of up to 50 and $70 \%$ have been reported in wheat for leaf rust (12) and stripe rust (4), respectively. Planting resistant cultivars is the most efficient, economical, and environmentally friendly way to manage these diseases.

Resistance to wheat rusts can be categorized as either race specific, which results from a range of hypersensitive responses to infection and is detected at the seedling or adult growth stages (7), or as slow-rusting adult plant resistance (APR) that is exhibited in the postseedling growth stages with delayed infection, reduced growth, and reproduction of the pathogen $(1,37)$. Race-specific resistance is generally qualitatively inherited, exhibiting hypersensitive reactions, with a resistance gene that interacts with the pathogen in a gene-for-gene manner, and rust fungi readily adapt with the emergence of new virulent races (13). In contrast, APR genes are usually quantitatively inherited, often non-race-specific, and have remained durable (37). Thus, identifying and characterizing sources of slow-rusting APR is essential for appropriate deployment in wheat breeding.

To date, more than 72 leaf rust and 56 stripe rust resistance genes have been officially designated (23) and several have been mapped with linked or diagnostic molecular markers. In addition, 80 and 140 quantitative trait loci (QTL) for leaf rust and stripe rust resistance, respectively, have been identified primarily through molecular markers and mapped to the wheat genome $(9,23)$. How-

Corresponding authors: C. X. Lan, E-mail: c.lan@cgiar.org; and S. A. Herrera-Foessel, E-mail: s.herrera@cgiar.org

Accepted for publication 16 March 2014.

http://dx.doi.org/10.1094/PDIS-07-13-0707-RE

(C) 2014 The American Phytopathological Society ever, traditional genetic analysis plays an important role in determining the genetic basis for resistance and identifying new sources of resistance. Some wheat cultivars, including 'Frontana', 'Pavon 76', 'Strampelli', 'Libellula', 'Capo', 'Bainong 64', and 'Claire' $(19,21,29,30,39,40)$ have provided durable resistance to rusts over several decades in different wheat production areas. Resistance to leaf or stripe rust in these and other wheat cultivars is often estimated to be caused by three to five genes, acting cumulatively with small to medium individual effects $(19,21,29,30,39,40)$.

The CIMMYT-derived common wheat 'Francolin\#1' (pedigree: 'Waxwing*2/Vivitsi') is a high-yielding stem rust resistant line that also possesses resistance to stripe rust and leaf rust. Francolin\#1 was released in India under the name 'Ufan' and in Bangladesh as 'BARI Gom 27'; in Nepal it is in the process of being released and it has performed outstandingly, with high yield and good rust resistance in the northeast Gangetic Plains of India, Nepal, and Bangladesh $(14,34)$.

This study aimed to (i) investigate the genetic basis of leaf rust and stripe rust resistance in an 'Avocet- $Y r A$ ' $\times$ Francolin\#1 recombinant inbred line (RIL) population at the seedling and adult plant stages, (ii) investigate the detection of known leaf rust and stripe rust resistance loci using molecular markers, and (iii) explore the interaction between seedling and APR loci.

\section{Materials and Methods}

Plant material. The $198 \mathrm{~F}_{4}$-derived $\mathrm{F}_{5}$ RILs used in this study were developed from a cross between common spring wheat parents Avocet-YrA and Francolin\#1. The susceptible parent Avocet$\operatorname{YrA}$ is a reselection line from Australian 'Avocet' that lacks the temporarily designated stripe rust resistance gene $\operatorname{YrA}$ and also showed susceptibility to leaf rust. For simplicity in this article, the two parents will be referred to as Avocet and Francolin. The RIL population was derived from three different $F_{1}$ plants. We used the pedigree approach for generation advancement; thus, random spikes were harvested in each generation and sown as hills. During population development, plants received fungicide applications to ensure that all genotypic representatives were kept in each generation. The tester line 'Avocet*3//Lalb Mono1*4/Pavon', with Lr46/Yr29, Waxwing, and Vivitsi, were also included in the study. 
Greenhouse trials. Leaf rust. Seedling tests to phenotype leaf rust resistance in Avocet, Francolin, Waxwing, Vivitsi, and 198 Avocet/Francolin $F_{5}$ RILs were conducted in greenhouse conditions in August 2011 with $P$. triticina race $\mathrm{MBJ} / \mathrm{SP}$, and repeated in September 2011 with races MBJ/SP and TBD/TM. Race TBD/TM was used to confirm the phenotyping results for $\operatorname{Lr} 16$, postulated to be present in Francolin, because Lrl6 confers a lower infection type with TBD/TM compared with race MBJ/SP. The avirulence/virulence formula of MBJ/SP is $L r 2 a, 2 b, 2 c, 3 k a, 9,16,18$, $19,21,24,25,(26), 28,29,30,32,33,36 / 1,3,3 b g, 10,11,13,15$, $17,20,23,27+31(11)$; and the avirulence/virulence formula of race $\mathrm{TBD} / \mathrm{TM}$ is $\operatorname{Lr} 9,11,16,19,21,23,24,25,26,29,30,32,33$, $36 / 1,2 a, 2 b, 2 c, 3,3 b g, 10,13,15,17,18,20,27+31,28$ (32). A set of 48 differential lines with known leaf rust resistance genes (most lines in the 'Thatcher' background), including 'RL6005' with Lr16, were included in the seedling tests as a check to compare the infection types of parents and RILs with known resistance genes. Each race was evaluated separately and 8 to 10 seeds of each RIL were sown as hills in trays containing 48 entries each. Inoculations were conducted when plants were at the two-leaf stage by spraying urediniospores suspended in lightweight mineral oil Soltrol 170 (Chempoint.com) using an atomizer. In order to let oil evaporate, the inoculated plants were left in an open place for around $30 \mathrm{~min}$ before transferring them into a dew chamber overnight, then transferred to a greenhouse. A data logger (LogTag analyzer. Ver. 1.9) was installed in the greenhouse and programmed to measure air temperature every $15 \mathrm{~min}$.

The minimum, maximum, and mean postinoculation temperatures for the leaf rust greenhouse experiments were 16.8, 29.1, and $23.0^{\circ} \mathrm{C}$, respectively. Leaf rust infection types were recorded 11 days postinoculation and were based on a 0 to 4 scale modified from Roelfs et al. (31), where $0=$ no visible symptoms, $1=$ small uredinia surrounded by necrosis, $2=$ small to medium uredinia surrounded by chlorosis or necrosis, $3 \mathrm{C}=$ medium uredinia with chlorosis, 3 = medium-sized uredinia without chlorosis or necrosis, $34=$ medium to large- sized uredinia without chlorosis or necrosis, 4 = large-sized uredinia without chlorosis or necrosis, $;=$ necrotic or chlorotic flecks, $X=$ random distribution of variable-sized uredinia, and + and - were used when uredinia were somewhat larger or smaller than normal for the infection type.

Stripe rust. Greenhouse seedling trials to phenotype stripe rust resistance of Avocet, Francolin, Waxwing, Vivitsi, and RILs were conducted three times (February 2011, August 2011, and September 2011), using the predominant Mexican $P$. striiformis isolate Mex96.11. In these experiments, 27 differential lines with known stripe rust resistance genes (mostly in Avocet background) were also included. The inoculation method was the same as described for leaf rust but the incubation temperature in the dew chamber was $7^{\circ} \mathrm{C}$. Inoculated plants were placed in the dew chamber for 48 $\mathrm{h}$, then transferred to a greenhouse.

The minimum, maximum, and mean postinoculation greenhouse temperatures were $10.8,24.6$, and $17.2^{\circ} \mathrm{C}$, respectively. Infection types, recorded about 2 weeks postinoculation, were based on a 0 to-9 scale modified from McNeal et al. (25), where $0=$ no visible infection, 1 = necrotic or chlorotic flecks without sporulation, $2=$ necrotic or chlorotic pustules without sporulation, $3=$ necrotic or chlorotic pustules with trace sporulation, $4=$ necrotic or chlorotic pustules with light sporulation, $5=$ necrotic or chlorotic pustules with intermediate sporulation, $6=$ chlorotic pustules with moderate sporulation, 67 = pustules without chlorosis or necrosis and with small sporulation, $7=$ pustules without chlorosis or necrosis and with moderate sporulation, $8=$ pustules without chlorosis or necrosis and with sufficient sporulation, and $9=$ pustules without chlorosis or necrosis and abundant sporulation.

Field trials. Leaf rust. The parents, Avocet/Francolin RILs, and tester line for $L r 46 / Y r 29$ were evaluated for APR to leaf rust at Ciudad Obregon, Sonora, Mexico, during the 2008-09 and 200910 crop seasons. Field plots consisted of $0.7-\mathrm{m}$ paired rows with approximately 60 plants of each line in the plot. The susceptible wheat 'Morocco' was planted around the experimental area and as hill plots on one side of each experimental plot, in the middle of a $0.3-\mathrm{m}$ pathway, as the leaf rust spreader plots. The spreader plots were inoculated around 20 January 2009 and 2010 with an equal mixture of urediniospores of $P$. triticina races $\mathrm{MBJ} / \mathrm{SP}$ and MCJ/SP, suspended in Soltrol 170. The main difference between the two races is partial and complete virulence for $L r 26$ in MBJ/SP and $\mathrm{MCJ} / \mathrm{SP}$, respectively. Disease severity on parents and RILs was recorded once in 2009 and twice in 2010 according to the modified Cobb scale after anthesis, when the susceptible parent displayed $80 \%$ or higher disease severity (28), and host response to infection was determined according to Roelfs et al. (31), where $\mathrm{R}=$ resistant, or miniature uredinia surrounded by necrotic tissues; MR $=$ moderately resistant, or smaller to moderate-sized uredinia surrounded by necrotic or chlorotic tissues; MS = moderately susceptible, or moderate-sized uredinia without necrotic or chlorotic tissues; and S = susceptible, or large uredinia without necrotic or chlorotic tissues. Leaf rust severity was rated when the disease severity on Avocet reached a maximum level, around the middle of March in both years.

Based on the disease severity and phenotypic responses, RILs were classified into three different categories, according to the methods of Singh and Rajaram (39): homozygous parental type resistant (HPTR), homozygous parental type susceptible (HPTS), and lines with different responses than the two parents (OTHER).

Stripe rust. The parents, Avocet/Francolin RILs, and tester line for $L r 46 / Y r 29$ were sown at the CIMMYT research station near Toluca, State of Mexico, Mexico, around the third week of May in 2009 and 2010. Field trials were established in a similar way to the leaf rust trials. Spreaders consisted of a mixture of six susceptible wheat lines derived from the Avocet $x$ 'Attila' cross known to carry the stripe rust resistance gene $Y r 27$. Spreaders and hills were inoculated with a mixture of $P$. striiformis isolates Mex96.11 and Mex08.13 approximately 1 month after sowing. The main difference between the two isolates is virulence for $\mathrm{Yr} 27$ and avirulence for $\operatorname{Yr} 31$ in Mex96.11, and the opposite in Mex08.13. The percentage stripe rust severity (28) and host response to infection (31) on the parents and RILs were recorded once in 2009 and twice in 2010 , where $\mathrm{R}=$ necrotic or chlorotic stripes without sporulation, $\mathrm{MR}=$ necrotic or chlorotic stripes with some sporulation, $\mathrm{M}$ (or MRMS) $=$ necrotic or chlorotic stripes with intermediate sporulation, MS = stripes without chlorosis and necrosis but with moderate sporulation, and $\mathrm{S}=$ stripes without chlorosis or necrosis and with abundant sporulation. Stripe rust severity was evaluated when the susceptible parent Avocet had reached 90 to $100 \%$ severity at milk stage onward for Avocet and middle dough stage for Francolin. RILs were then classified into the three phenotypic stripe rust response categories, as explained for leaf rust.

Molecular analysis. Genomic DNA was extracted using the cetyltrimethylammonium bromide method described by CIMMYT (3) from approximately 20 plants per line. In total, 11 molecular markers previously reported to be associated with known slowrusting APR genes were used to screen the parents. These markers included simple sequence repeats (SSR)/sequence-tagged site molecular markers such as Xgwm533 and csSr2 linked to $\operatorname{Sr} 2 / \mathrm{Yr} 30$ $(8,20)$, Lr34/Yrl8 gene sequence-based markers cssfrl-cssfr5 (18), csLV46 closely linked to Lr46/Yr29 (17), Xgwm192 and Xgwm165 closely linked to $L r 67 / Y r 46$ (10), and $\operatorname{csGS}$ associated with $\operatorname{Lr68}$ (11). In addition, because Francolin was postulated to carry racespecific leaf rust resistance gene Lrl6, based on infection type and pedigree, three previously reported Lrl6-linked SSR markers$X w m c 382, X w m c 764$, and Xgwm210 (22) were also tested on the parents. Markers csLV46, Xgwm533, Xgwm210, Xwmc382, and $X w m c 764$ were found to be polymorphic between the parents and used to screen the entire RIL population. Polymerase chain reactions (PCRs) were performed in volumes of $10 \mu \mathrm{l}$ containing $0.06 \mu \mathrm{l}$ of Taq DNA polymerase (Promega Corp.) at $5 \mu / \mu \mathrm{l}, 2 \mu \mathrm{l}$ of $5 \times$ PCR buffer (Promega Corp.), $0.74 \mu \mathrm{l}$ of $25 \mathrm{mM} \mathrm{MgCl}$ (Promega Corp.), $0.7 \mu \mathrm{l}$ of dNTP, $2.5 \mu \mathrm{l}$ of $1 \mathrm{mM}$ SSR primers, and $4 \mu \mathrm{l}$ of template DNA at $15 \mathrm{ng} / \mu \mathrm{l}$. The PCR conditions were a denaturation at $94^{\circ} \mathrm{C}$ for $3 \mathrm{~min}$; followed by 35 cycles of $94^{\circ} \mathrm{C}$ for 
$1 \mathrm{~min}, 55$ to $65^{\circ} \mathrm{C}$ (depending on primer pair) for $1 \mathrm{~min}$, and $72^{\circ} \mathrm{C}$ for $1 \mathrm{~min}$; and a final extension at $72^{\circ} \mathrm{C}$ for $5 \mathrm{~min}$. Each sample was loaded on $10 \%$ polyacrylamide gels (29:1) with silver staining used to visualize the amplification products (3).

Genetic and statistical analysis. The number of genes segregating for leaf and stripe rust resistance in the Avocet/Francolin RIL population was estimated using Mendelian segregation analysis $(15,39)$, where the observed frequencies for each category (HPTR:HPTS:OTHER) were tested against the expected frequencies for different numbers of additive genes using $\chi^{2}$ analysis. Calculations for phenotypic effects of leaf and stripe rust seedling resistance genes, response of molecular markers, their additive combined effects, and tests of statistical significance for pairwise comparisons of the means were conducted using the PROC GLM and $t$ test in SAS software (SAS Institute). For the analysis of phenotypic effects, leaf rust infection types $1,1+$, and $3 \mathrm{C}$ were considered resistant and $3+$ and 4 were susceptible; for stripe rust infection types, 34 to 6 were considered resistant and 67 to 9 as susceptible.

\section{Results}

Resistance phenotyping of seedlings in greenhouse. Leaf rust. Seedling infection types were 4 and $3+$ for Avocet, $3+$ and $3 \mathrm{C}$ for Vivitsi, and $3 \mathrm{C}$ and 1 for Francolin and Waxwing with $P$. triticina races $\mathrm{MBJ} / \mathrm{SP}$ and TBD/TM, respectively (Table 1 ). For both $P$.

Table 1. Leaf and stripe rusts infection types displayed by Avocet, Francolin, and three checks in seedling greenhouse tests with Puccinia triticina races $\mathrm{MBJ} / \mathrm{SP}$ and $\mathrm{TBD} / \mathrm{TM}$ and Puccinia striiformis isolate Mex96.11

\begin{tabular}{lcccc}
\hline & \multicolumn{3}{c}{ Infection type $^{\mathbf{x}}$} \\
\cline { 2 - 3 } Parents. checks & \multicolumn{2}{c}{ Leaf rust $^{\mathbf{y}}$} & & Stripe rust $^{\mathbf{z}}$ \\
\cline { 2 - 3 } & MBJ/SP & TBD/TM & & Mex96.11 \\
\hline Avocet & 4 & $3+$ & \\
Francolin & $3 \mathrm{C}$ & 1 & 38 \\
Waxwing & $3 \mathrm{C}$ & 1 & 67 \\
Vivitsi & $3+$ & $3 \mathrm{C}$ & 56 \\
RL6005 (Lr16) & $1+3 \mathrm{C}$ & 1 & - \\
\hline
\end{tabular}

${ }^{\mathrm{x}}$ Leaf rust and stripe rust infection types follow 0-4 and 0-9 Scales, respectively, as described by Roelfs et al. (31).

${ }^{\mathrm{y}}$ Leaf rust infection type: $1=$ small uredinia surrounded by necrosis, $3 \mathrm{C}=$ medium uredinia with chlorosis, $3=$ medium-sized uredinia without chlorosis or necrosis, $4=$ large-sized uredinia without chlorosis or necrosis, and + was used when uredinia were somewhat larger than normal for the infection type. For the analysis of phenotypic effects, leaf rust infection types $1,1+$, and $3 \mathrm{C}$ were considered resistant and $3+$ and 4 were susceptible.

${ }^{\mathrm{z}}$ Stripe rust infection type: $34=$ necrotic or chlorotic pustules with trace and light sporulation, $56=$ necrotic or chlorotic pustules with intermediate to moderate sporulation, $67=$ pustules without chlorosis or necrosis and with small sporulation, and $78=$ pustules without chlorosis or necrosis and with moderate to sufficient sporulation. For the analysis of phenotypic effects, stripe rust infection types 34 to 6 were considered resistant and 67 to 9 were susceptible. triticina races, Francolin and Waxwing had resistance reaction similar to the Lr16 tester RL6005 (Table 1), and this seedling resistance gene was also closely linked to molecular marker Xgwm 210 (within 2.7 centimorgans in $198 \mathrm{~F}_{5}$ RILs). This indicates that $L r 16$ conferred seedling resistance to leaf rust in Francolin and that it was most likely derived from the Waxwing parent. For both races in the greenhouse tests, the number of resistant and susceptible RILs in the population conformed to the expected frequency of a single gene based on $\chi^{2}$ analysis, using three sets of seedling phenotypic data with races MBJ/SP and TBD/TM (Table 2).

Stripe rust. The infection types that developed with $P$. striiformis isolate Mex96.11 on Avocet, Francolin, Waxwing, and Vivitsi were $78,34,67$, and 56, respectively, at the seedling stage in the greenhouse (Table 1). The distribution of RILs corresponded to the segregation of a single gene (Table 2), temporarily designated as $\mathrm{YrF}$. The distribution of 159 homozygous RILs for leaf rust and stripe rust (namely, $48 \mathrm{Lrl6YrF}, 53 \mathrm{lrl6yrF}, 29 \mathrm{Lrl6yrF}$, and 29 $\operatorname{lr} 16 Y r F)$ was significant $\left(\chi_{1: 1: 1: 1}^{2}=11.94, P<0.007\right)$ for the segregation of two independent genes, indicating that $\mathrm{Lrl6}$ and $\mathrm{YrF}$ are linked, with a recombination frequency of 0.36 .

Resistance phenotyping in field trials. Leaf rust. The final disease severity and reaction to leaf rust for Avocet and Francolin were 90 to $100 \% \mathrm{~S}$ and 0 to $1 \% \mathrm{MS}$, respectively, at the adult plant stage (milk stage onward for Avocet and middle dough stage for Francolin) during the two crop seasons, whereas leaf rust severity of the tester line for $\mathrm{Lr} 46 / \mathrm{Yr} 29$ was 20 to $30 \% \mathrm{MS}-\mathrm{S}$ reaction. The frequency distribution of RILs for leaf rust severity indicated quantitative inheritance of APR (Fig. 1A), though the distribution was

Table 2. Estimated number of resistance genes that conferred seedling and adult plant resistance to leaf and stripe rusts in 198 Avocet/Francolin $\mathrm{F}_{5}$ recombinant inbred lines (RILs) based on Mendelian segregation analysis

\begin{tabular}{lccccc}
\hline & \multicolumn{4}{c}{ Number of RILs } \\
\cline { 2 - 3 } & \multicolumn{2}{c}{ Adult plant $^{\mathbf{x}}$} & & \multicolumn{2}{c}{ Seedling } \\
\cline { 2 - 3 } \cline { 5 - 6 } Category $^{\mathbf{z}}$ & Leaf rust & Stripe rust $^{\mathbf{y}}$ & & Leaf rust & Stripe rust \\
\hline HPTR & 8 & 2 & & 86 & 90 \\
HPTS & 15 & 2 & & 91 & 87 \\
OTHER & 174 & 193 & & 20 & 20 \\
$N$ & 3 & 5 & & 1 & 1 \\
$P$ value & 0.08 & 0.65 & & 0.57 & 0.60 \\
\hline
\end{tabular}

${ }^{x}$ Based on disease severity and host response to infection over two seasons of field data: leaf rust at Ciudad Obregon in the 2008-09 and 2009-10 seasons and stripe rust at Toluca during the 2009 and 2010 seasons.

${ }^{y}$ Based on two and one tests with Puccinia triticina races MBJ/SP and TBD/TM, respectively, and three tests with $P$. striiformis f. sp. tritici race Mex96.11 in the greenhouse.

${ }^{\mathrm{z}}$ Response category: HPTR $=$ homozygous parental type resistant, HPTS $=$ homozygous parental type susceptible, OTHER $=$ lines with responses different from the two parents, and $\mathrm{N}=$ number of genes. $P$ value is for the $\chi^{2}$ test. The expected ratios of RILs grouped under HPTR, HPTS, and OTHER are 0.438:0.438:0.125, 0.084:0.084:0.833, and 0.016:0.016:0.968 for segregation of one, three, and five independently inherited genes, respectively, in the $\mathrm{F}_{4: 5}$ generation.
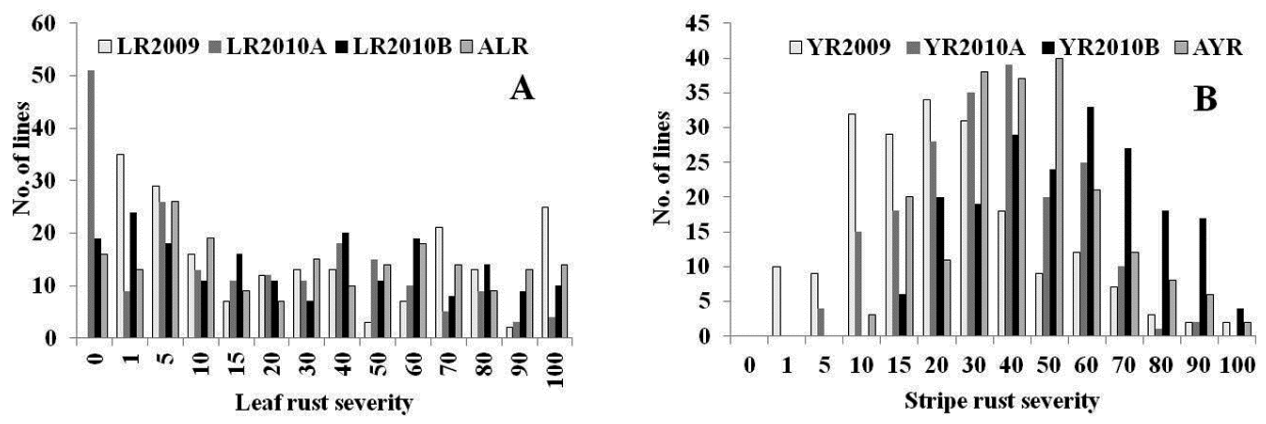

Fig. 1. Frequency distributions of Avocet/Francolin $F_{5}$ recombinant inbred lines (RILs) in field trials. A, Leaf rust severity recorded once in 2009 and twice in 2010 (2010A and 2010B), and mean severity using 2009 and 2010B data. B, Stripe rust severity recorded once in 2009 and twice in 2010 (2010A and 2010B), and mean severity using 2009 and 2010B data. 
skewed toward the resistant parent. Assuming that resistance genes acted in an additive manner, the frequencies of RILs in three phenotypic categories (i.e., HPTR, HPTS, and OTHER) were in accordance with segregation at three independent loci (Table 2). Based on closely linked molecular markers, one of the resistance loci was identified as the slow-rusting APR gene Lr46. The leaf rust severity of RILs with this gene was 1 to $60 \%$, whereas severity of RILs without this gene was 5 to $100 \%$ (Fig. 2A). A mean disease severity reduction of 34 to $55 \%$ was obtained for RILs with Lr46 compared with RILs without this gene across three readings and mean final disease severity (Table 3 ). Leaf rust severity of RILs with and without the seedling effective race-specific resistance gene Lrl6 showed similar ranges in the adult plant stage (Fig. 2B). Although the leaf rust severity means of RILs with Lr16 were about 7 to $9 \%$ lower than RILs without this gene, the difference was not significant, except for the early reading recorded in 2010. $\mathrm{YrF}$ appeared to have no significant effects on leaf rust severity (Table 3 ).
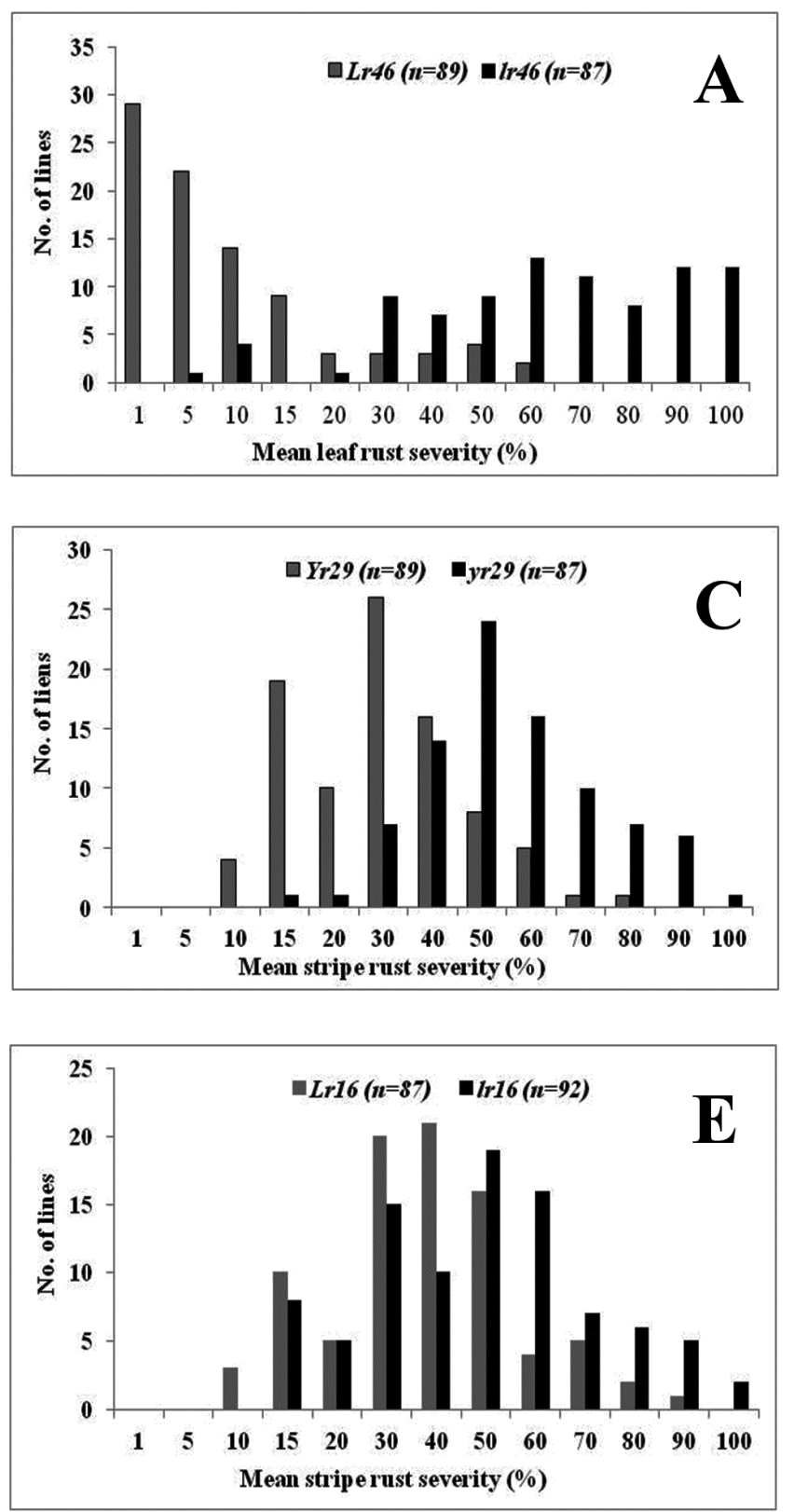

Stripe rust. The final stripe rust severities and reactions for Avocet and Francolin were $90 \mathrm{~S}$ and 1 to $10 \mathrm{R}-\mathrm{MR}$, respectively, at the adult plant stage during the two crop seasons. Stripe rust severity of the $L r 46 / Y r 29$ tester was 60 to $70 \%$. The frequency distribution of RILs for stripe rust severity also showed continuous variation, suggesting quantitative inheritance of APR to stripe rust (Fig. 1B). The frequencies of RILs in three phenotypic categories (i.e., HPTR, HPTS, and OTHER) concurred with segregation at five independent loci, based on the assumption that resistance genes act in an additive manner (Table 2).

Yr29 was one of the stripe rust APR genes that contributed to overall resistance. Mean disease severity of RILs with Yr29 was 10 to $80 \%$, whereas disease severity of RILs without this gene was 15 to $100 \%$ (Fig.2C). A mean stripe rust severity reduction of 18 to $31 \%$ was obtained for RILs with Yr29, compared with RILs without it (Table 3). Gene $\operatorname{YrF}$ that conferred moderate seedling resistance also had a significant effect on stripe rust resistance at the adult plant stage in both crop seasons, with a mean reduction of 11
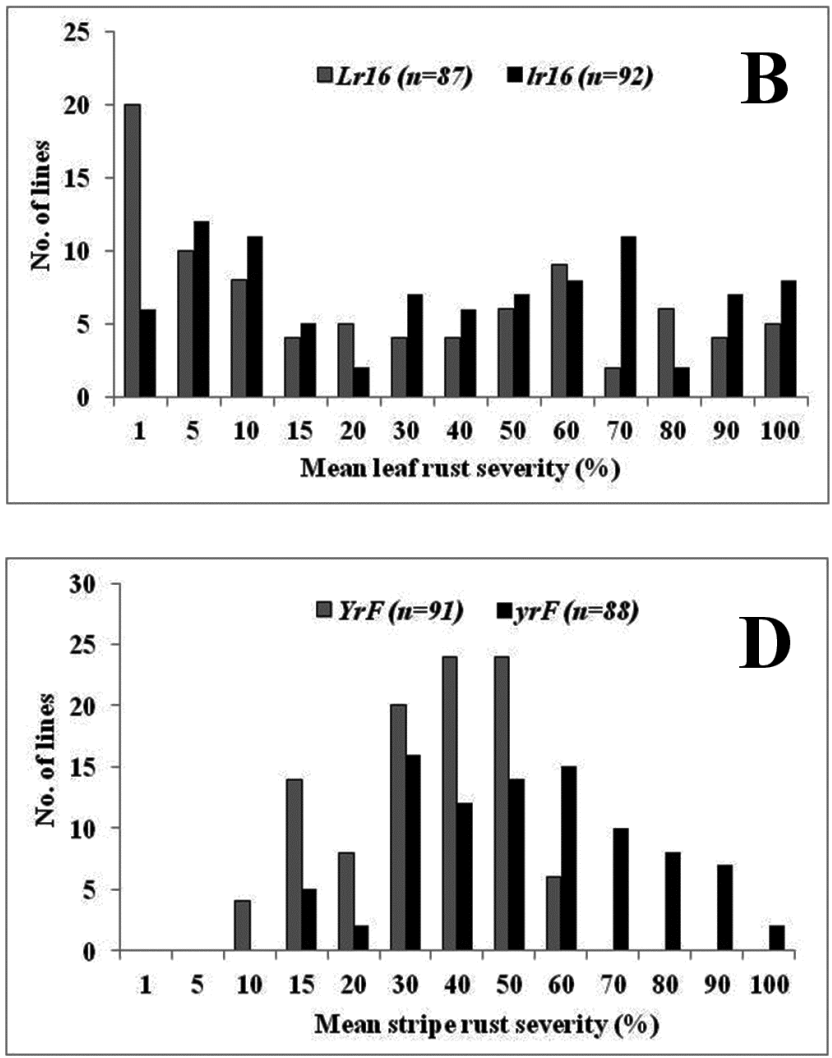

Fig. 2. Comparison of Avocet/Francolin recombinant inbred lines (RILs) for mean leaf rust severity (using 2009 and $2010 \mathrm{~B}$ data) and mean stripe rust severity (using 2009 and 2010B data) in the presence or absence of postulated resistance genes in field trials. A, Effect of Lr46 on leaf rust, present (Lr46) and absent (Ir46). B, Effect of Lr16 on leaf rust, present (Lr16) and absent (Ir16). C, Effect of Yr29 on stripe rust, present (Yr29) and absent (yr29). D, Effect of YrF on stripe rust, present (YrF) and absent (yrF). E, Effect of $L r 16$ on stripe rust, present (Lr16) and absent (Ir16). The number of RILs in each category is shown in parentheses. 
to $25 \%$ in disease severity (Table 3 ). The mean disease severity of RILs with $\mathrm{YrF}$ was 10 to $60 \%$ whereas, for RILs without this gene, the range was 15 to $100 \%$ (Fig. 2D). Moreover, a significant mean reduction of 5 to $16 \%$ in stripe rust severity was associated with the presence of Lr16 in RILs (Table 3). The mean stripe rust severity for RILs was 10 to $90 \%$ when Lr16 was present, compared with 15 to $100 \%$ when absent (Fig. 2E).

Correlation analysis. Leaf rust severity of Avocet/Francolin RILs was significantly correlated between the 2 years and was 0.85 to 0.93 (Table 4). Stripe rust also correlated significantly across the 2 years and was 0.68 to 0.93 (Table 4). There was a significant correlation between leaf rust and stripe rust severities of 0.52 to 0.74 (Table 4). The high correlation might be due to common pleiotropic APR genes such as $Y r 29 / L r 46$, or linkage between other pairs of leaf rust and stripe rust resistance genes such as $\mathrm{Lrl6}$ and $\mathrm{YrF}$.

Additive interactions between the detected resistance genes. The additive interactions between the slow-rusting APR gene
Lr46/Yr29 and seedling resistance genes $L r 16$ and $Y r F$ were investigated using leaf rust and stripe rust severity data from field trials. We used the closely linked molecular marker $c s L V 46$ and infection type at seedling stage to determine the presence or absence of the three resistance genes. Although slight reductions in leaf rust severity occurred when Lr46 and Lrl6 were present together, the additive interaction was not significant (Table 5). In contrast, significant additive interactions were found between $\operatorname{Lr} 16$ and $Y r 29$, and between $\mathrm{YrF}$ and $\mathrm{Yr} 29$, with mean stripe rust severity reductions of 8 to $10 \%$ (Table 6) and 9 to $17 \%$ (Table 7), respectively.

\section{Discussion}

Francolin was highly resistant to leaf and stripe rusts in field trials at two different field sites in Mexico. The resistance in Avocet/Francolin $\mathrm{F}_{5}$ RILs was shown to be controlled by a combination of seedling and APR loci. We detected three and five loci that conferred leaf rust and stripe rust resistance, respectively, in adult

Table 3. Frequencies of Avocet/Francolin recombinant inbred lines (RILs) with resistance genes $L r 16$ (based on seedling reaction), $L r 46 / Y r 29$, and $Y r F$, their mean leaf rust and stripe rust severities, and $t$ test for the comparison of pairs when resistance genes were absent or present

\begin{tabular}{|c|c|c|c|c|c|c|c|c|c|c|}
\hline \multirow[b]{3}{*}{ Trait, gene } & & & \multicolumn{8}{|c|}{ Mean disease severities $(\%)^{\mathrm{v}}$} \\
\hline & \multicolumn{2}{|c|}{$\operatorname{RILs}(N)$} & \multicolumn{2}{|c|}{$2009^{w}$} & \multicolumn{2}{|c|}{$2010 A^{x}$} & \multicolumn{2}{|c|}{$2010 B^{y}$} & \multicolumn{2}{|c|}{$\operatorname{Mean}^{z}$} \\
\hline & Absent & Present & Absent & Present & Absent & Present & Absent & Present & Absent & Present \\
\hline \multicolumn{11}{|l|}{ Leaf rust } \\
\hline Lr16 & 92 & 87 & $42 \mathrm{~A}$ & $33 \mathrm{~A}$ & $28 \mathrm{~A}$ & $20 \mathrm{~B}$ & $38 \mathrm{~A}$ & $31 \mathrm{~A}$ & $40 \mathrm{~A}$ & $32 \mathrm{~A}$ \\
\hline Lr46 & 87 & 89 & $64 \mathrm{~A}$ & $9 \mathrm{~B}$ & $41 \mathrm{~A}$ & $7 \mathrm{~B}$ & $57 \mathrm{~A}$ & $11 \mathrm{~B}$ & $61 \mathrm{~A}$ & $10 \mathrm{~B}$ \\
\hline$Y r F$ & 88 & 91 & $39 \mathrm{~A}$ & $35 \mathrm{~A}$ & $28 \mathrm{~A}$ & $21 \mathrm{~A}$ & $37 \mathrm{~A}$ & $33 \mathrm{~A}$ & $38 \mathrm{~A}$ & $34 \mathrm{~A}$ \\
\hline \multicolumn{11}{|l|}{ Stripe rust } \\
\hline Lr16 & 92 & 87 & $34 \mathrm{~A}$ & $22 \mathrm{~B}$ & $38 \mathrm{~A}$ & $33 \mathrm{~B}$ & $58 \mathrm{~A}$ & $50 \mathrm{~B}$ & $46 \mathrm{~A}$ & $30 \mathrm{~B}$ \\
\hline $\operatorname{Yr} 29$ & 87 & 89 & $36 \mathrm{~A}$ & $18 \mathrm{~B}$ & $47 \mathrm{~A}$ & $24 \mathrm{~B}$ & $69 \mathrm{~A}$ & $38 \mathrm{~B}$ & $53 \mathrm{~A}$ & $28 \mathrm{~B}$ \\
\hline$Y r F$ & 88 & 91 & $40 \mathrm{~A}$ & $15 \mathrm{~B}$ & $41 \mathrm{~A}$ & $30 \mathrm{~B}$ & $60 \mathrm{~A}$ & $48 \mathrm{~B}$ & $50 \mathrm{~A}$ & $32 \mathrm{~B}$ \\
\hline
\end{tabular}

${ }^{\mathrm{v}}$ Different letters within rows following the mean indicates significant differences based on $t$ test $(P<0.01)$.

${ }^{\mathrm{w}}$ Leaf and stripe rusts severities were determined at Ciudad Obregon (2008-09 season) and Toluca (2009 season), respectively.

${ }^{x}$ Leaf and stripe rusts severities determined on the first date of evaluation at Ciudad Obregon (2009-10 season) and Toluca (2010 season), respectively.

${ }^{y}$ Leaf and stripe rusts severities determined on the second date of evaluation at Ciudad Obregon (2009-10 season) and Toluca (2010 season), respectively.

${ }^{\mathrm{z}}$ Mean of final leaf rust (2009 and 2010B) and stripe rust severities (2009 and 2010B), respectively.

Table 4. Phenotypic correlations for leaf rust (Ciudad Obregon, 2008-09 and 2009-10) and stripe rust (Toluca, 2009 and 2010) severities for 198 Avocet/Francolin recombinant inbred lines

\begin{tabular}{|c|c|c|c|c|c|}
\hline \multirow[b]{2}{*}{ Environment } & \multicolumn{5}{|c|}{ Environment $^{\mathrm{t}}$} \\
\hline & LR2009u & LR2010A & LR2010B & YR2009 & YR2010A \\
\hline LR2010A ${ }^{v}$ & $0.85 * *$ & $\ldots$ & $\ldots$ & $\ldots$ & $\ldots$ \\
\hline LR2010B w & $0.89 * *$ & $0.93 * *$ & $\ldots$ & $\ldots$ & $\ldots$ \\
\hline YR2009x & $0.54 * *$ & $0.52 * *$ & $0.53 * *$ & $\ldots$ & $\ldots$ \\
\hline YR2010A & $0.71 * *$ & $0.66^{* *}$ & $0.69 * *$ & $0.72 * *$ & $\ldots$ \\
\hline YR2010Bz & $0.76 * *$ & $0.70 * *$ & $0.74 * *$ & $0.68 * *$ & $0.93 * *$ \\
\hline
\end{tabular}

${ }^{\mathrm{t}}$ Asterisks $(* *)$ indicate $P<0.0001$.

" Leaf rust severities at Ciudad Obregon in the 2008-09 season.

${ }^{\mathrm{v}}$ Leaf rust severities on the first date of evaluation at Ciudad Obregon in the 2009-10 season.

${ }^{\mathrm{w}}$ Leaf rust severities on the second date of evaluation at Ciudad Obregon in the 2009-10 season.

${ }^{x}$ Stripe rust severities at Toluca during the 2009 season.

${ }^{y}$ Stripe rust severities on the first date of evaluation at Toluca in the 2010 season.

${ }^{\mathrm{z}}$ Stripe rust severities on the second date of evaluation at Toluca in the 2010 season.

Table 5. Additive interactions between the slow-rusting adult plant resistance gene $L r 46$ and race-specific resistance gene $L r 16$ for leaf rust resistance in adult plant stage in Avocet/Francolin $\mathrm{F}_{5}$ recombinant inbred lines (RILs) across two seasons

\begin{tabular}{|c|c|c|c|c|c|c|}
\hline \multicolumn{2}{|c|}{ Status of resistance gene } & \multirow[b]{2}{*}{$\operatorname{RILs}(N)$} & \multicolumn{4}{|c|}{ Mean leaf rust severity $(\%)^{\mathrm{v}}$} \\
\hline Lr46 & Lr16 & & $2009^{w}$ & $2010 A^{x}$ & $2010 B^{y}$ & $\operatorname{Mean}^{\mathrm{z}}$ \\
\hline Absent & Absent & 48 & $65 \mathrm{~A}$ & $40 \mathrm{~A}$ & $55 \mathrm{~A}$ & $60 \mathrm{~A}$ \\
\hline Absent & Present & 32 & $61 \mathrm{~A}$ & $39 \mathrm{~A}$ & $57 \mathrm{~A}$ & $59 \mathrm{~A}$ \\
\hline Present & Absent & 37 & $12 \mathrm{~B}$ & $11 \mathrm{~B}$ & $15 \mathrm{~B}$ & $13 \mathrm{~B}$ \\
\hline Present & Present & 44 & $8 \mathrm{~B}$ & $4 \mathrm{~B}$ & $8 \mathrm{~B}$ & $8 \mathrm{~B}$ \\
\hline
\end{tabular}

${ }^{\mathrm{v}}$ Different letters following the mean in the same column indicates significant differences based on $t$ test $(P<0.01)$.

${ }^{\text {w }}$ Determined at Ciudad Obregon during the 2008-09 seasons.

${ }^{x}$ Determined on the first date of evaluation at Ciudad Obregon in the 2009-10 seasons.

${ }^{y}$ Determined on the second date of evaluation at Ciudad Obregon in the 2009-10 seasons.

${ }^{\mathrm{z}}$ Mean of final severity in 2008 and 2009 and the second date of evaluation at Ciudad Obregon in the 2009-10 seasons. 
plants, and one gene for each rust disease in the seedling stage. Among these, slow-rusting APR gene Lr46/Yr29 and seedling resistance genes $L r 16$ and $\mathrm{YrF}$ could be identified using molecular markers or seedling infection types. $\operatorname{Lr} 16$ and $\operatorname{YrF}$ were loosely linked with a recombination frequency of 0.36 .

Although the race-specific resistance gene Lr16 may have a small effect in reducing leaf rust severity in adult plants to the same avirulent races as at the seedling stage, the mean difference was not significant except in 2010, when data were recorded at an earlier phase of disease development. Singh and Huerta-Espino (35) reported that Lrl6 confers only moderate resistance to the Mexican $P$. triticina race TCB/TD in adult plants and behaves like a slow-rusting resistance gene, with final leaf rust severity of 70 to $80 \%$ in the adult plants stage, when present alone (35). Leaf rust severities and reactions of 28 Chinese varieties possessing $\mathrm{Lr} 16$ were $10 \mathrm{MS}-\mathrm{S}$ to $100 \mathrm{~S}$ in the field trials in Mexico using avirulent races (33). Similarly, Lrl6 had no significant effect on leaf rust severity in the adult plant stage in Avocet/Francolin $F_{5}$ RILs, indicating that, although Lrl6 is effective in the seedling stage, it confers only slight resistance to leaf rust in adult plants, which is difficult to detect in the presence of other resistance genes. Lr16 showed small but significant effects in reducing stripe rust severity in adult plants, which could be attributed to possibly another stripe rust APR gene present that is closer to $\mathrm{Lr} 16 / \mathrm{Xgwm} 210$ region, because $\operatorname{YrF}$ is probably too distant to account for the effect of the Lr16/Xgwm 210 region on stripe rust severity. Lr16 in Francolin is derived from the resistant parent Waxwing, because the other parent Vivitsi was susceptible to $P$. triticina race $\mathrm{MBJ} / \mathrm{SP}$ in seedling tests. This gene is more effective at higher temperatures and is linked to $\operatorname{Sr} 23(5,24)$. The frequency of Lr16 has increased in CIMMYT germplasm in recent years, with a greater number of lines derived from Waxwing parentage (36). According to HuertaEspino et al. (12), Lrl6-virulent races were detected in northern America, Canada, China, India, Iran, and Syria but the frequency of virulence to $\operatorname{Lr} 16$ has decreased from 35.5 to $0.6 \%$ during the last 10 years in Canada. Even if Lr16 virulence dominates fields in the northern Great Plains region of the United States, the Thatcher tester line carrying Lr16 remains resistant in the field, and the hard red spring wheat cultivars with $\operatorname{Lrl6}$ were also highly resistant for more than 10 years in Minnesota and the Dakotas (16). In our study, Lr16 displayed infection type 3C against the predominant race $\mathrm{MBJ} / \mathrm{SP}$; this infection type could easily be misinterpreted as a susceptible response, resulting in an accidental identification of the race as virulent.

The stripe rust resistance gene $Y r F$ effective in Francolin in seedlings may derive from the Vivitsi parent, because Waxwing was susceptible to P. striiformis isolates Mex96.11 and Mex08.13 at the seedling stage. The seedling reactions of RILs postulated to carry $\mathrm{YrF}$ varied from 34 to 6, indicating that $\mathrm{YrF}$ had only a small effect in reducing seedling reactions to stripe rust, and that it can be influenced by the genetic background and environment. We had to repeat seedling tests three times to convincingly postulate the presence and absence of $Y r F$ in RILs. The effect of $\operatorname{YrF}$ was also moderate in field trials: about a $40 \%$ reduction in stripe rust severity when present alone, based on the distribution of $\mathrm{F}_{5}$ RILs for severity responses. However, we did not detect any significant effects of this gene on leaf rust. Further mapping analysis will confirm whether $\operatorname{YrF}$ is a previously reported or a novel gene.

The slow-rusting APR gene Lr46/Yr29 present in Francolin was originally identified in Pavon 76 by Singh et al. (38) and located to chromosome arm 1BL by William et al. (42). It has provided slowrusting APR to leaf and stripe rusts for more than 40 years. In our field trials, the reductions in leaf and stripe rusts severity for the tester line containing $L r 46 / Y r 29$ were 70 to $80 \%$ and 30 to $40 \%$, respectively. $\mathrm{F}_{5}$ RILs predicted to carry this APR gene alone had approximately 40 and $20 \%$ reductions in mean leaf rust and stripe rust severities, respectively. Similar effects were found by William et al. (42), who reported that $L r 46 / Y r 29$ reduced leaf and stripe rusts severities by 41 to $54 \%$ and 19 to $39 \%$, respectively.

Singh et al. (34) reported that the APR gene $S r 2 / Y r 30$ could be present in Francolin due to the incidence of pseudoblack chaff, which is a morphological marker closely linked to this gene. Molecular marker $\mathrm{Xgwm533}$, closely linked to $\mathrm{Sr} 2$ (8), was present in Francolin and segregated in the RIL population. However, singlemarker analysis did not indicate associations between Xgwm533 and stripe rust resistance in the RIL population. Another molecular marker, $c s S r 2$ (20), was also tested on parents to confirm the presence of $S r 2 / Y r 30$. However, the two parents were not polymorphic and lacked the positive allele.

Table 6. Additive interactions between the slow-rusting adult plant resistance gene $\operatorname{Yr} 29$ and race-specific resistance gene $\operatorname{Lr} 16$ for stripe rust resistance in the adult plant stage in Avocet/Francolin $\mathrm{F}_{5}$ recombinant inbred lines (RILs) across two seasons

\begin{tabular}{|c|c|c|c|c|c|c|}
\hline \multicolumn{2}{|c|}{ Status of resistance gene } & \multirow[b]{2}{*}{ RILs $(N)$} & \multicolumn{4}{|c|}{ Mean stripe rust severity $(\%)^{\mathrm{v}}$} \\
\hline Yr29 & Lr16 & & $2009^{w}$ & $2010 A^{x}$ & $2010 B^{y}$ & $\operatorname{Mean}^{\mathrm{z}}$ \\
\hline Absent & Absent & 48 & $40 \mathrm{~A}$ & $48 \mathrm{~A}$ & $70 \mathrm{~A}$ & $55 \mathrm{~A}$ \\
\hline Absent & Present & 32 & $30 \mathrm{~B}$ & $46 \mathrm{~A}$ & $66 \mathrm{~A}$ & $48 \mathrm{~B}$ \\
\hline Present & Absent & 37 & $24 \mathrm{~B}$ & $25 \mathrm{~B}$ & $42 \mathrm{~B}$ & $33 \mathrm{C}$ \\
\hline Present & Present & 44 & $14 \mathrm{C}$ & $23 \mathrm{~B}$ & $36 \mathrm{~B}$ & $25 \mathrm{D}$ \\
\hline
\end{tabular}

${ }^{\mathrm{v}}$ Different letters following means in the same column indicate significant differences based on $t$ test $(P<0.01)$.

${ }^{\mathrm{w}}$ Determined at Toluca during the 2009 season.

${ }^{x}$ Determined on the first date of evaluation at Toluca in the 2010 season.

y Determined on the second date of evaluation at Toluca in the 2010 season.

${ }^{\mathrm{z}}$ Mean of final severity in 2009 and the second date of evaluation at Toluca during the 2010 season.

Table 7. Additive interactions between the slow-rusting adult plant resistance gene $\operatorname{Yr} 29$ and seedling resistance gene $\operatorname{YrF}$ for stripe rust resistance in adult plant stage in Avocet/Francolin $\mathrm{F}_{5}$ recombinant inbred lines (RILs) across two seasons

\begin{tabular}{|c|c|c|c|c|c|c|}
\hline \multicolumn{2}{|c|}{ Status of resistance gene } & \multirow[b]{2}{*}{ RILs $(N)$} & \multicolumn{4}{|c|}{ Mean stripe rust severity $(\%)^{v}$} \\
\hline Yr29 & $\operatorname{YrF}$ & & $2009^{w}$ & $2010 A^{x}$ & $2010 B^{y}$ & Mean $^{z}$ \\
\hline Absent & Absent & 39 & $52 \mathrm{~A}$ & $54 \mathrm{~A}$ & $76 \mathrm{~A}$ & $64 \mathrm{~A}$ \\
\hline Absent & Present & 39 & $20 \mathrm{~B}$ & $40 \mathrm{~B}$ & $62 \mathrm{~B}$ & $41 \mathrm{~B}$ \\
\hline Present & Absent & 37 & $27 \mathrm{~B}$ & $28 \mathrm{C}$ & $43 \mathrm{C}$ & $35 \mathrm{~B}$ \\
\hline Present & Present & 42 & $10 \mathrm{C}$ & $19 \mathrm{D}$ & $32 \mathrm{D}$ & $21 \mathrm{C}$ \\
\hline
\end{tabular}

${ }^{\mathrm{v}}$ Different letters following means in the same column indicate significant differences based on $t$ test $(P<0.01)$.

${ }^{\mathrm{w}}$ Determined at Toluca during the 2009 season.

${ }^{x}$ Determined on the first date of evaluation at Toluca in the 2010 season.

${ }^{y}$ Determined on the second date of evaluation at Toluca in the 2010 season.

${ }^{z}$ Mean of final severity in 2009 and the second date of evaluation at Toluca during the 2010 season. 
We did not detect significant additive effects between the genes Lr16 and Lr46/Yr29 in reducing leaf rust severity in field trials, though a small but significant additive effect was found for stripe rust. The lack of interaction effects for leaf rust is likely due the fact that the effect of $\operatorname{Lrl6}$ was small in reducing leaf rust severity of the two races used in our field trials (Fig 2B). Oelke and Kolmer (27) indicated that high levels of leaf rust resistance in hard red spring wheat cultivars from Minnesota and the Dakotas involved combinations of the seedling resistance gene Lr16 or Lr24 with additional APR genes. Vanzetti et al. (41) also reported that 9 of the 11 wheat cultivars with high levels of resistance to all pathotypes in Argentina showed combinations of seedling resistance genes, among which Lrl6 played a central role in developing germplasm with high level of resistance to leaf rust in Argentina. In Canada, a positive interaction for leaf rust resistance was also found between $\operatorname{Lr} 16, \operatorname{Lr} 13$, and $L r 34$, with lower seedling infection types and higher field resistance than either of the seedling or APR genes alone (6), indicating that Lrl6 plays an important resistance role in the adult plant stage in the United States, Argentina, and Canada. This does not apply to the $P$. triticina races currently dominant in Mexico but a significant additive effect was detected between Lr16 and $\mathrm{Yr} 29$ for adult plant stripe rust resistance in our study.

Since Francolin's original distribution by CIMMYT in 2008, it has continued to confer resistance worldwide to all three rusts. Singh et al. (34) reported that the stem rust severity of Francolin was around $10 \%$ for the Ug99 race group in Kenya. Our study shows that resistance to leaf rust and stripe rust is complex in Francolin, which makes it a valuable parent in breeding programs for achieving durable resistance to the leaf rust, stripe rust, and stem rust. The chromosome location, effect and interaction between seedling resistance genes ( $\mathrm{Lrl}$ l6 and $\mathrm{YrF}$ ) and slow-rusting APR loci ( $L r 46 / Y r 29$ and other) in Francolin are under further investigation.

\section{Acknowledgments}

We thank the Grains Research and Development Corporation (GRDC) of Australia for funding this study, SAGARPA-CONACYT of Mexico (Fondo Sectorial project 146788) for partial support, and E. Quilligan for editing.

\section{Literature Cited}

1. Caldwell, R. M. 1968. Breeding for general and/or specific plant disease resistance. Pages 263-272 in: Proc. Int. Wheat Genet. Symp. 3rd. K. W. Finlay and K. W. Shepherd, eds.

2. Chen, X. M. 2005. Epidemiology and control of stripe rust (Puccinia striiformis f. sp. tritici) on wheat. Can. J. Plant Pathol. 27:314-337.

3. CIMMYT. 2005. Laboratory Protocols: CIMMYT Applied Molecular Genetics Laboratory, 3rd ed. CIMMYT, Mexico City, Mexico.

4. Dedryver, F., Paillard, S., Mallard, S., Robert, O., Trotter, M., Nègre, S., Verplancke, G., and Jahier, J. 2009. Characterization of genetic components involved in durable resistance to stripe rust in the bread wheat 'Renan'. Phytopathology 99:968-973.

5. Dyck, P. L., and Johnson, R. 1983. Temperature sensitivity of genes for resistance in wheat to Puccinia recondita. Can. J. Plant Pathol. 5:229-234.

6. German, S. E., and Kolmer, J. A. 1992. Effect of gene Lr34 in the enhancement of resistance to leaf rust of wheat. Theor. Appl. Genet. 84:97-105.

7. Gustafson, G., and Shaner, G. 1982. Influence of plant age on the expression of slow-mildewing resistance in wheat. Phytopathology 72:746-749.

8. Hayden, M. J., Kuchel, H., and Chalmers, K. J. 2004. Sequence tagged microsatellites for the Xgwm533 locus provides new diagnostic markers to select for the presence of stem rust resistance gene $\mathrm{Sr} 2$ in bread wheat (Triticum aestivum L.). Theor. Appl. Genet. 109:1641-1647.

9. He, Z. H., Lan, C. X., Chen, X. M., Zou, Y. C., Zhuang, Q. S., and Xia, X. C. 2011. Progress and perspective in research of adult-plant resistance to stripe rust and powdery mildew in wheat. Sci. Agric. Sin. 44:2199-2215.

10. Herrera-Foessel, S. A., Lagudah, E. S., Huerta-Espino, J., Hayden, M. J., Bariana, H. S., Singh, D., and Singh, R. P. 2011. New slow-rusting leaf rust and stripe rust resistance genes $\mathrm{Lr67}$ and $\mathrm{Yr} 46$ in wheat are pleiotropic or closely linked. Theor. Appl. Genet. 122:239-249.

11. Herrera-Foessel, S. A., Singh, R. P., Huerta-Espino, J., Rosewarne, G. M., Periyannan, S. K., Viccars, L., Calvo-Salazar, V., Lan, C. X., and Lagudah, E. S. 2012. Lr68: A new gene conferring slow rusting resistance to leaf rust in wheat. Theor. Appl. Genet. 124:1475-1486.

12. Huerta-Espino, J., Singh, R. P., Germán, S., McCallum, B. D., Park, R. F., Chen, W. Q., Bhardwaj, S. C., and Goyeau, H. 2011. Global status of wheat leaf rust caused by Puccinia triticina. Euphytica 179:143-160.
13. Johnson, R. 1981. Durable resistance: Definition, genetic control, and attainment in plant breeding. Phytopathology 71:567-568.

14. Joshi, A. K., Azab, M., Mosaad, M., Osmanzai, M., Gelalcha, S., Bedada, G., Bhatta, M. R., Hakim, A., Malaker, P. K., Haque, M. E., Tiwari, T. P., Majia, A., Kamali, M. R. J., Bishaw, Z., Singh, R. P., Payne, T., and Braun, H. J. 2010. Delivering rust resistant wheat to farmers: A step towards increased food security. Euphytica 179:187-196.

15. Knott, D. R., and Padidam, M. 1988. Inheritance of resistance to stem rust in six wheat lines having adult plant resistance. Genome 30:283-288.

16. Kolmer, J. A., Jin, Y., and Long, D. L. 2007. Leaf and stem rust of wheat in the United States. Aust. J. Agric. Res. 58:631-638.

17. Kolmer, J. A., Lin, M., and Bai, G. 2012. Genetics of leaf rust resistance in the winter wheat line CI13227. Crop Sci. 52:2166-2172.

18. Lagudah, E. S., Krattinger, S. G., Herrera-Foessel, S. A., Singh, R. P., Huerta-Espino, J., Spielmeyer, W. G., Brown-Guedira, G., Selter, L. L., and Keller, B. 2009. Gene-specific markers for the wheat gene Lr34/Yr18/Pm38 which confers resistance to multiple fungal pathogens. Theor. Appl. Genet. 119:889-898.

19. Lu, Y. M., Lan, C. X., Liang, S. S., Zhou, X. C., Liu, D., Zhou, G., Lu, L. Q., Jing, J. X., Wang, M. N., Xia, X. C., and He, Z. H. 2009. QTL mapping for adult-plant resistance to stripe rust in Italian common wheat cultivars Libellula and Strampelli. Theor. Appl. Genet. 119:1349-1359.

20. Mago, R., Brown-Guedira, G., Dreisigacker, S., Breen, J., Jin, Y., Singh, R., Appels, R., Lagudah, E. S., Ellis, J., and Spielmeyer, W. 2011. An accurate DNS marker assay for stem rust resistance gene $S r 2$ in wheat. Theor. Appl. Genet. 122:735-744.

21. Matiasch, L., Buerstmayr, M., Herzog, K., Kraic, J., Šudyová, V., Šliková, S., Löschenberger, F., Marn, M., Lafferty, J., Ittu, M., Vida, G., Mascher, F., Hartl, L., Flath, K., and Buerstmary, H. 2011. QTL mapping of adult plant leaf rust and stripe rust resistance derived from the Australian winter wheat cultivar Capo. 2011 Tagung der Vereinigung der Pflanzenzüchter und Saatgutkaufleute Österreichs, Raumberg-Gumpenstein 131.

22. McCartney, C. A., Somers, D. J., McCallum, B. D., Thomas, J., Humphreys, D. G., Menzies, J. G., and Brown, P. D. 2005. Microsatellite tagging of the leaf rust resistance gene Lr16 on wheat chromosome 2BS. Mol. Breed. 15:329-337.

23. McIntosh, R. A., Dubcovsky, J., Rogers, W. J., Morris, C. F., Appels, R., and Xia, C. X. 2012. Catalogue of Gene Symbols for Wheat: 2012 (Suppl.). http://www.shigen.nig.ac.jp/wheat/komugi/genes/symbolClassList.jsp;jsessi onid=82FB82BE7FE833C40CB82EAB6305D786.4 5

24. McIntosh, R. A., and Luig, N. H. 1973. Linkage of genes for reaction to Puccinia graminis f. sp. tritici and $P$. recondita in Selkirk wheat and related cultivars. Aust. J. Biol. Sci. 26:1145-1152.

25. McNeal, F. H., Konzak, C. F., Smith, E. P., Tate, W. S., and Russell, T. S. 1971. A uniform system for recording and processing cereal research data. U.S. Dep. Agric. Agric. Res. Serv. Bull. 34-121.

26. Milus, E. A., Kristensen, K., and Hovmǿller, M. S. 2009. Evidence for increased aggressiveness in a recent widespread strain of Puccinia striiformis f. sp. tritici causing stripe rust of wheat. Phytopathology 99:89-94.

27. Oelke, L. M., and Kolmer, J. A. 2004. Characterization of leaf rust resistance in hard red spring wheat cultivars. Plant Dis. 88:1127-1133.

28. Peterson, R. F., Campbell, A. B., and Hannah, A. E. 1948. A diagrammatic scale for estimating rust intensity on leaves and stems of cereals. Can. J. Res. 26:496-500.

29. Powell, N. M., Lewis, C. M., Berry, S. T., MacCormack, R., and Boyd, L. A. 2013. Stripe rust resistance genes in UK winter wheat cultivar Claire. Theor. Appl. Genet. 126:1599-1612.

30. Ren, Y., Li, Z. F., He, Z. H., Wu, L., Bai, B., Lan, C. X., Wang, C. F., Zhou, G., Zhu, H. Z., and Xia, X. C. 2012. QTL mapping of adult-plant resistance to stripe rust and leaf rust in Chinese wheat cultivar Bainong 64. Theor Appl. Genet. 125:1253-1262.

31. Roelfs, A. P., Singh, R. P., and Saari, E. E. 1992. Rust Diseases of Wheat: Concepts and Methods of Disease Management. CIMMYT, Mexico, D.F.

32. Singh, R. P. 1991. Pathogenicity variations of Puccinia recondita f. sp. tritici and $P$. graminis $\mathrm{f}$. sp. tritici in wheat-growing areas of Mexico during 1988 and 1989. Plant Dis. 75:790-794.

33. Singh, R. P., Chen, W. Q., and He, Z. H. 1999. Leaf rust resistance of spring, facultative, and winter wheat cultivars from China. Plant Dis. 83:644-651.

34. Singh, R. P., Hodson, D. P., Huerta-Espino, J., Jin, Y., Bhavani, S., Njau, P., Herrera-Foessel, S., Singh, P. K., Singh, S., and Govindan, V. 2011. The emergence of Ug99 races of the stem rust fungus is a threat to world wheat production. Annu. Rev. Phytopathol. 49:465-481.

35. Singh, R. P., and Huerta-Espino, J. 1995. Inheritance of seedling and adult plant resistance to leaf rust in wheat cultivars Ciano 79 and Papago 86. Plant Dis. 79:35-38.

36. Singh, R. P., Huerta-Espino, J., Bhavani, S., Herrera-Foessel, S. A., Jin, Y., Njau, P., Singh, P. K., Velu, G., Singh, S., Peña, R. J., and Crossa, J. 2011. High yielding CIMMYT spring wheats with resistance to Ug99 and other rusts developed through targeted breeding. Pages 98-104 in: 2011 Borlaug Global Rust Initiative Technical Workshop.

37. Singh, R. P., Huerta-Espino, J., and William H. M. 2005. Genetics and breeding for durable resistance to leaf and stripe rusts in wheat. Turk. J. Agric. For. 29:121-127. 
38. Singh, R. P., Mujeeb-kazi, A., and Huerta-Espino, J. 1998. Lr46: A gene conferring slow-rusting resistance to leaf rust in wheat. Crop Sci. 37:390395.

39. Singh, R. P., and Rajaram, S. 1992. Genetics of adult-plant resistance to leaf rust in 'Frontana' and three CIMMYT wheats. Genome 35:24-31.

40. Singh, R. P., William, H. M. J., Huerta-Espino, J., and Rosewarne, G. 2004. Wheat rust in Asia: Meeting the challenges with old and new technology. In: New Directions of a Diverse Planet: Proc. 4th Crop Sci. Congress, Brisbane, Australia. Regional Inst. Gosford, NSW, Australia. http://www.crop science.org.au/icsc2004/symposia/3/7/141_singhrp.htm
41. Vanzetti, L. S., Campos, P., Demichelis, M., Lombardo, L. A., Aurelia, P. R., Vaschetto, L. M., Bainotti, C. T., and Helguera, M. 2011. Identification of leaf rust resistance genes in selected Argentinean bread wheat cultivars by gene postulation and molecular markers. Electron. J. Biotechnol. 14 http://www.ejbiotechnology.info/index.php/ejbiotechnology/article/view/v1 4n3-14/1313

42. William, M., Singh, R. P., Huerta-Espino, J., Ortiz Islas, S., and Hoisington, D. 2003. Molecular marker mapping of leaf rust resistance gene Lr46 and its association with stripe rust resistance gene $\mathrm{Yr} 29$ in wheat. Phytopathology 93:153-159.

\section{Erratum}

A correction was made to this article on August 21, 2014. On the first page, the order of the authors was changed. 